\title{
PENERAPAN METODE WEIGHTED PRODUCT UNTUK SELEKSI KELULUSAN SANTRI PADA SISTEM INFORMASI WISUDA TAMAN PENDIDIKAN AL-QURAN (TPA) UNIVERSITAS DARUSSALAM GONTOR
}

\author{
Dihin Muriyatmoko* ${ }^{*}$, Triana Harmini ${ }^{2}$, Muhamad Nuradi Arrahmantoro ${ }^{3}$ \\ 1,2,3Program Studi Teknik Informatika, Fakultas Sains dan Teknologi, Universitas Darussalam Gontor Satu \\ Email: ${ }^{1}$ dihin@unida.gontor.ac.id, ${ }^{2}$ triana@unida.gontor.ac.id, ${ }^{3}$ muhamad.nuradi@unida.gontor.ac.id
}

(Naskah masuk: 17 November 2020, diterima untuk diterbitkan: 22 Maret 2021)

\begin{abstract}
Abstrak
Setiap tahun, pada bulan Desember dilaksanakan acara wisuda bagi santri TPA binaan Universitas Darussalam Gontor (UNIDA Gontor) yang dinyatakan lulus ujian. Para santri tersebut harus lulus empat tahapan ujian, yaitu lisan, praktik, tulis dan Al-Quran. Pada sistem penilaian yang ada saat itu, masih menggunakan perhitungan ratarata. Padahal menurut evaluasi para Ustadz dan kepala Lembaga Pengabdian kepada Masyarakat (LPkM) mestinya ujian Al-Quran menjadi prioritas utama. Maka hasil evaluasi memberi rekomendasi bahwa ujian AlQuran wajib dimasukkan dalam prioritas utama dengan bobot paling besar sebagai acuan penentuan kelulusan. Untuk mendapatkan sebuah prioritas dalam penilaian perlu sebuah metode yang memberikan bobot nilai yang multi attribute, diantaranya Weight Product (WP). Tujuan penelitian ini adalah menerapkan metode WP untuk seleksi kelulusan santri wisuda TPA UNIDA Gontor dalam bentuk sistem informasi. Pengembangan sistem informasi berbasis web menggunakan bahasa pemrograman PHP dan MySQL. Pengujian sistem dilakukan dengan metode black box dan kuesioner. Pengujian sistem menggunakan metode black box menghasilkan alur dan rangkaian sistem yang diharapkan tanpa ada error. Pengujian sistem dengan penyebaran kuesioner menggunakan skala Likert menghasilkan nilai rata-rata keseluruhan sebesar 4,47 dengan rentang kepuasan "tinggi". Hasil dari penerapan metode WP ini sudah berjalan sesuai prioritas nilai ujian sesuai dengan aturan LPkM. Pada penelitian berikutnya bisa dikembangkan dengan metode lain diantaranya SAW, TOPSIS, AHP, ARAS dan lain sebagainya.
\end{abstract}

Kata kunci: weighted product, wisuda, sistem informasi wisuda, taman pendidikan al-qur'an, UNIDA Gontor

\section{IMPLEMENTATION OF WEIGHTED PRODUCT METHOD FOR STUDENT GRADUATION SELECTION ON QURANIC SCHOOL GRADUATION INFORMATION SYSTEM OF UNIVERSITY OF DARUSSALAM GONTOR}

\begin{abstract}
Every year, in December, a graduation ceremony is held for TPA students assisted by the University of Darussalam Gontor (UNIDA Gontor) who have passed the exam. The students must pass four stages of the exam: oral, practical, written, and Al-Quran. In the current rating system, it is still using the average calculation. According to the evaluation of the teacher and the head of LPkM, the Al-Quran exam should be the top priority. Then the assessment has a recommendation to gives direction to the stages of the Al-Quran examination included in the top priority. To prioritize the review needs a multi-attribute weight value method, including Weight Product (WP). This study aims to apply the WP method to select prospective students graduating from TPA UNIDA Gontor in the form of information systems. Development of Web-based information systems using PHP and MySQL programming languages. System testing has done using black-box testing and the questionnaire. Testing using the black-box produces expected system paths and sequences without any errors. Testing the system by distributing questionnaires using a Likert scale provides an overall average value of 4.47 with a "high" satisfaction range. The results of the WP method's application have been running according to the priority of the test scores by the rules of LPkM. Other methods can be applied in further research, including SAW, TOPSIS, AHP, ARAS, etc.
\end{abstract}

Keywords: weighted product, graduation, graduation information system, Quranic school, UNIDA Gontor 


\section{PENDAHULUAN}

Lembaga Pengabdian kepada Masyarakat (LPkM) Universitas Darussalam Gontor merupakan salah satu Lembaga yang menaungi semua aktifitas pengabdian masyarakat yang didirikan sejak tahun 1998. Salah satu bentuk pengabdian yang dilaksanakan adalah memberikan layanan pendidikan kepada santri Taman Pendidikan AlQuran (TPA) yang ada desa sekitar kampus. Diantara kegiatan rutin tahunan TPA, mulai 2018 diadakan wisuda bagi santri TPA yang lulus ujian seleksi. Para santri yang sudah wisuda diberikan wewenang untuk mengajarkan ilmu yang telah mereka dapatkan kepada orang lain (Universitas Darussalam Gontor, 2018).

Pada sistem informasi yang ada saat itu, santri dinyatakan lulus seleksi dan berhak mengikuti wisuda jika mendapatkan rata-rata nilai minimal 60 . Nilai tersebut diambilkan dari empat tahap ujian, yaitu lisan, praktik, tulis dan Al-Quran. Setelah dua tahun, para Ustadz dan kepala LPkM melaksanakan evaluasi terhadap penilaian seleksi ini. Hasilnya mereka memberikan prioritas bahwa untuk ujian AlQuran harus dijadikan prioritas tertinggi dibandingkan dengan ujian lisan dan praktik. Sedangkan untuk ujian tulis mendapat prioritas terendah. Evaluasi tentang prioritas nilai tersebut dilakukan karena kekhawatiran atas keutamaan ilmu yang perlu didahulukan.

Untuk mendapatkan bobot prioritas nilai ujian, membutuhkan sebuah metode yang multi attribute. Diantara metode yang sesuai untuk menyelesaikan masalah tersebut adalah Weight Product (WP). Maka dalam penelitian ini diusulkan metode WP yang digunakan untuk pengambilan keputusan kelulusan dengan pembobotan nilai ujian pada aspek tertentu. Sehingga, tujuan dari penelitian ini adalah menerapkan metode WP untuk seleksi kelulusan santri TPA binaan Universitas Darussalam Gontor kedalam dalam sistem informasi wisuda.

\section{METODE PENELITIAN}

\subsection{Tahapan SDLC (Systems Development Life Cycle) Model Waterfall}

Model Waterfall digunakan untuk mendesain langkah dalam penelitian ini seperti pada gambar 1 .

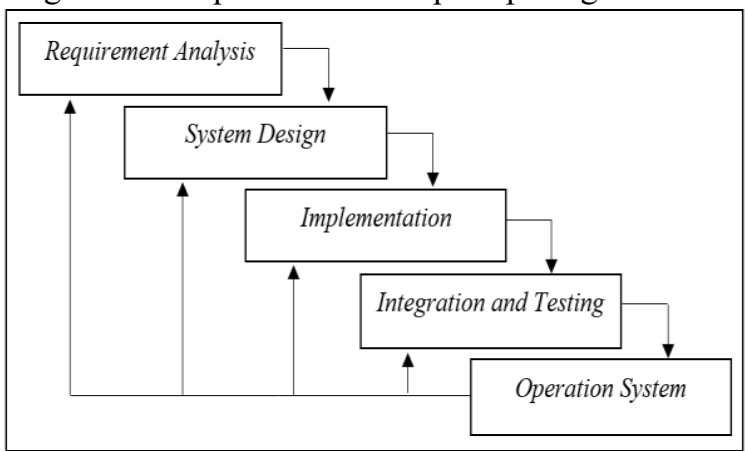

Gambar 1. Siklus Perancangan Sistem dengan Metode Waterfall (Sommerville, 2010)
Fase-fase yang diterapkan dalam perancangan sistem, meliputi:

a. Requirements analysis, untuk mendapatkan data kebutuhan aplikasi, peneliti melakukan wawancara, survey dan diskusi dengan pengurus DPM periode 2017/2018 dan jajaran staf LPkM. Hasil dari fase analisis ini adalah rekomendasi yang diberikan oleh Ustadz pengajar TPA dan kepala LPkM untuk memberikan proiritas bobot nilai pada sistem informasi wisuda TPA.

b. System Design, peneliti merancang desain basis data yang digunakan, desain rancangan antarmuka sistem (mockup), alur kerja aplikasi (Data Flow Diagram), dan menspesifikasikan kebutuhan hardware dan software. Pada tahap ini sistem pengambilan keputusan yang diterapkan pada seleksi kelulusan santri diubah dari model ratarata menjadi model pembobotan nilai tertentu pada tiap tahap ujiannya.

c. Implementation, peneliti menggunakan bahasa pemrograman $P H P$ dan $M Y S Q L$ dikarenakan system sebelumnya juga menggunakan database dan Bahasa pemrograman yang sama. Tahap ini melanjutkan peneliti menerapkan metode WP untuk dimasukkan ke system informasi wisudah untuk bagian seleksi kelulusan santri.

d.Integration dan Testing, dalam pengujian sistem, peneliti menggunakan metode black box besting untuk memudahkan proses dokumentasi. Hasil dari pengetesan system informasi menggunakan metode black box menunjukkan bahwa semua bagian sistem sudah berjalan tanpa ada eror.

e. Operation merupakan tahap akhir dimana peneniti sudah menilaikan sistem yang dibuat kepada pihak terkait

\subsection{Flowchart Proses Perhitungan Nilai}

Flowchart perhitungan nilai merupakan alur proses perhitungan metode WP yang diterapkan dalam sistem untuk menentukan peserta lulus dan Tidak seperti pada gambar 2 .

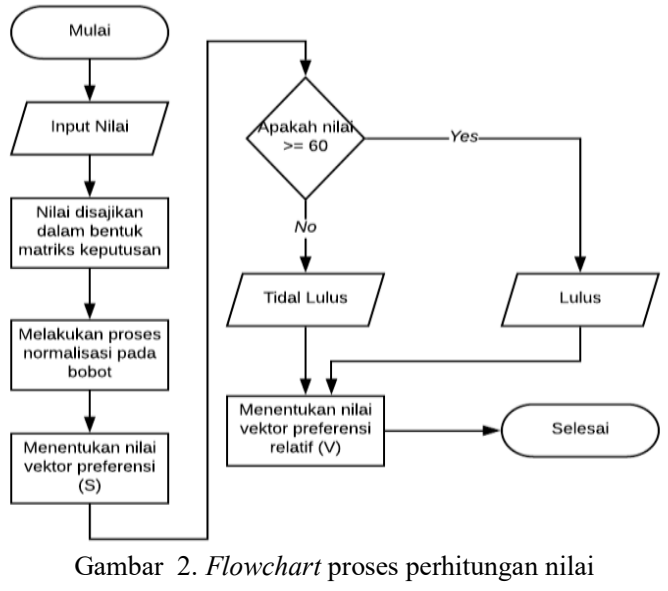

Alur penerapan metode WP dalam menentukan kelulusan, meliputi: 
1) Memasukkan nilai peserta secara keseluruhan.

2) Membuat matrik keputusan untuk meletakkan seluruh nilai yang dimiliki masing-masing alternatif sesuai dengan kriterianya.

3) Proses normalisasi nilai bobot setiap kriteria. Normalisasi dilakukan untuk mengalihkan hasil penilaian setiap kriteria.

4) Menentukan nilai vektor preferensi (S). Vektor preferensi difungsikan untuk mendapat nilai hasil rata-rata dengan.

5) Pengambilan keputusan untuk menentukan kelulusan. Penentuan keputusan kelulusan di dalam sistem berdasarkan nilai vektor preferensi $(S)$. Jika nilai $S$ lebih 60 maka dinyatakan lulus dan jika nilai $S$ di bawah 60 maka dinyatakan tidak lulus.

6) Menentukan nilai vektor preferensi relatif $(V)$. Vektor preferensi relatif merupakan preferensi alternatif yang akan digunakan untuk proses perangkingan masing-masing alternatif.

\subsection{Analisis Data}

Analisis data memberikan keterangan kriteria sebagai bahan untuk proses penentuan kelulusan. Kriteria diperoleh dari hasil musyawarah panitia penyelenggara. Dari hasil musyawarah, kriteria diputuskan menjadi 4 bagian yaitu ujian Al-qur'an, ujian hafalan, ujian praktik, dan ujian tulis. Bobot tingkatan kepentingan kriteria disajikan pada tabel 1.

\begin{tabular}{cc} 
Tabel 1. Tingkat Kepentingan & \\
\hline Tingkat Kepentingan & Bobot \\
\hline Sangat Penting (SP) & 5 \\
Penting (P) & 4 \\
Cukup penting (CP) & 3 \\
Tidak Penting (TP) & 2 \\
Sangat Tidak Penting (STP) & 1 \\
\hline
\end{tabular}

Hasil nilai bobot tiap kriteria diputuskan secara langsung oleh kepala LPkM yaitu Al-Ustadz Noor Syahid, M.Pd. dengan rincian berikut:

\begin{tabular}{clc}
\multicolumn{2}{c}{ Tabel 2. Hasil Penentuan bobot kriteria } \\
\hline No. & \multicolumn{1}{c}{ Kriteria $\left(\boldsymbol{C}_{\mathbf{i}}\right)$} & Bobot \\
\hline 1 & Al-Qur'an $\left(C_{1}\right)$ & 5 \\
2 & Hafalan $\left(C_{2}\right)$ & 3 \\
3 & Praktik $\left(C_{3}\right)$ & 3 \\
4 & Tulis $\left(C_{4}\right)$ & 2 \\
\hline
\end{tabular}

\section{TINJAUAN PUSTAKA}

\subsection{Penelitian Sejenis}

Penelitian yang dilakukan oleh Sucipto tentang pemilihan rekomendasi pembimbing praktek kerja lapangan yang sesuai dengan kebutuhan untuk memfasilitasi mahasiswa. Hasil dari penelitian tersebut berupa pembagian rekomendasi dosen pembimbing terhadap kelompok mahasiswa sesuai dengan urutan nilai tertinggi (Sucipto, 2017). Penelitian lain oleh Mustafidah dkk tahun 2017 untuk pemilihan mahasiswa lulusan terbaik menghasilkan alternatif mahasiswa lulusan terbaik di
Fakultas Teknik UMP Purwokerto (Mustafidah dan Hadyan, 2017).

Penelitian sejenis lainnya oleh Septya Maharani dkk, untuk pemilihan Taman Kanak-Kanak (TK) menggunakan metode WP di Kecamatan sungai Kunjang Samarinda. Penelitian ini memberikan rekomendasi TK yang sesuai dengan harapan orang tua untuk menjadi pertimbangan dalam memilih sekolah yang tepat. Sehingga untuk memilih satu dari 28 TK khususnya di Kecamatan sungai Kunjang, Samarinda menjadi lebih mudah (Maharani et al., 2018).

\subsection{Metode Weighted Product (WP)}

Metode WP termasuk salah satu metode yang digunakan untuk pendukung keputusan. Metode tersebut mengevaluasi lebih dari satu alternatif terhadap beberapa kriteria. Dimana setiap atribut tidak saling ketergantungan. Metode WP menggunakan model perkalian untuk hubungan atributnya, yang mana rating tiap atribut harus dipangkatkan dahulu dengan bobot tertentu (Nofriansyah and Defit, 2017). Kelebihan WP adalah sederhana dan bisa menentukan pembobotan kriteria yang mempunyai nilai mirip. WP lebih unggul dibandingkan TOPSIS. WP juga mempunyai kelemahan pada pengambilan keputusan yaitu tidak memiliki cost sehingga bisa menyebabkan kesalahan pemilihan alternatif saat perhitungan. (Purwandani, Husodo and Bimantoro, 2019).

Namun jika dibandingan dengan SAW metode WP masih memiliki kelemahan pada nilai dan bobot yang telah ditentukan (Wira Trise Putra and Agustian Punggara, 2018). Selain itu metode WP juga lebih baik dibandingkan dengan AHP (Analytical Hierarchy Process), TOPSIS (Technique for The Order of Preference by Similarity to The Ideal Solution) dan WSM (Weighted Sum Method). Namun jika dibandingkan dengan metode PROMETHE (Preference Ranking Organization Method for Enrichment Evaluation) dan ELEKTRE (Elimination Et Choix Traduisant La Realité (ELECTRE) metode WP masih kalah akurat (Kolios, Mytilinou and Lozano-minguez, 2016). Maka dari itu WP dipilih dalam penelitian ini karena lebih unggul dari SAW, WSM dan AHP. Langkahlangkah yang dilakukan dalam penyelesaian masalah pengambilan keputusan menggunakan metode WP (Khairina, Ivando dan Maharani, 2016).

\section{1) Normalisasi atau Perbaikan Bobot}

Pada penentuan perhitungan metode WP mengharuskan untuk menentukan prioritas bobot pada setiap kriterianya. Setelah langkah penentuan, setiap nilai bobot dilakukan normalisasi untuk mengalihkan hasil penilaian setiap kriteria. Bobot untuk kriteria berfungsi sebagai pangkat positif dalam proses perhitungan disetiap nilai alternatif, sementara bobot biaya (cost) berfungsi sebagai pangkat negative (Nofriansyah and Defit, 2017). 
Untuk melakukan normalisasi bobot dapat menggunakan rumus perhitungan berikut:

$$
\begin{aligned}
& W_{j}=\frac{w_{j}}{\sum w_{j}} \\
& \text { Keterangan: } \\
& W_{j}: \text { Total jumlah keseluruhan bobot } \\
& w_{j}: \text { Bobot kriteria ke- } j, j=1,2, \ldots, n
\end{aligned}
$$

Proses normalisasi bobot $W_{j}$ dapat dilakukan dengan cara menjumlahkan seluruh nilai bobot kriteria $\sum w_{j}$ dan melakukan proses pembagian pada setiap nilai bobot kriteria $w_{j}$ dengan hasil penjumlahan nilai bobot kriteria (Khairina, Ivando dan Maharani, 2016).

\section{2) Menentukan Nilai Vektor Preferensi $(S)$}

Langkah ini difungsikan untuk mendapatkan nilai rata-rata di setiap alternatif. Untuk mendapatkan vektor preferensi (S) dapat menggunakan rumus perhitungan berikut:

$$
\begin{aligned}
& S_{i}=\prod_{j=1}^{n} x_{i j} w_{j} \\
& \text { Keterangan: } \\
& S_{i}: \text { Preferensi alternatif ke- } j \\
& x_{i j}: \text { Nilai alternatif ke- } i \text { pada kriteria ke- } j \\
& W_{j}: \text { Normalisasi bobot kriteria ke- } j \\
& i: \text { Banyak alternatif dengan } i=1,2, \ldots, m \\
& j: \text { Banyak kriteria dengan } j=1,2, \ldots, n
\end{aligned}
$$

Untuk menentukan nilai vektor preferensi (S) dilakukan dengan cara mengalikan seluruh kriteria dengan alternatif hasil normalisasi bobot yang berpangkat positif untuk kriteria keuntungan (benefit) dan yang berpangkat negatif untuk kriteria biaya (cost) (Khairina, Ivando dan Maharani, 2016).

\section{3) Menentukan Nilai Vektor Preferensi Relatif}

( $V$ )

Nilai vektor preferensi relatif $(V)$ digunakan menghitung preferensi $(V i)$ pada proses perangkingan terhadap hasil yang telah didapat dari proses perhitungan vektor preferensi (S). Nilai preferensi relatif dari setiap alternatif dapat dihitung dengan rumus berikut:

$$
\begin{aligned}
& V_{i}=\frac{\prod_{j=1}^{n} x_{i j} w_{j}}{\prod_{j=1}^{n}\left(X_{j^{*}}\right) w_{j}}, \text { dengan } i=1,2, \ldots, n \\
& \text { Keterangan: } \\
& \begin{aligned}
& V: \text { Preferensi alternatif yang dianalogikan } \\
& \quad \text { sebagai vektor }
\end{aligned} \\
& x \quad: \text { Nilai kriteria } \\
& W: \text { Normalisasi bobot kriteria } \\
& i \quad: \text { Alternatif } \\
& j \quad: \text { Kriteria } \\
& n: \text { Banyaknya kriteria }
\end{aligned}
$$

Vektor (V) merupakan preferensi alternatif yang akan digunakan untuk perangkingan masing-masing alternatif. Nilai preferensi dapat dihasilkan dengan tepat jika setiap nilai akhir vektor preferensi (S) yang diperoleh telah dilakukan pembagian dengan jumlah keseluruhan nilai akhir vektor (S) (Khairina, Ivando dan Maharani, 2016).

\subsection{Jenis Ujian Kelulusan Santri TPA Binaan UNIDA Gontor}

Tujuan dari wisuda ini untuk menguji potensi santri didik sebelum mereka terjun secara langsung pada masyarakat luas untuk mengamalkan ilmu yang mereka dapatkan selama menempuh pendidikan di TPA. Untuk dapat mengikuti wisuda, santri wajib mengikuti 4 ujian sebagai berikut:

\section{1) Ujian Lisan (Munaqosah)}

Ujian munaqosah merupakan ujian lisan untuk menguji hafalan santri tentang surat-surat pendek dan ayat-ayat pilihan di dalam Al-Qur'an serta hafalan do'a harian. Ujian munaqosah meliputi Hafalan surat An-Naas sampai dengan Ad-Dhuha, Hafalan Do'a harian dan Hafalan ayat-ayat pililhan.

\section{2) Ujian Praktik}

Ujian Praktik merupakan ujian untuk mengetahui kebenaran hafalan dan gerakan santri dalam melaksanakan seluruh rukun ibadah sholat. Ujian praktik meliputi praktik wudhu, praktik sholat dan dzikir dan praktik adzan (putra) dan iqomah (putra/putri).

\section{3) Ujian Tulis}

Ujian Tulis merupakan ujian menulis Arab untuk mengetahui tingkat pemahaman santri dalam hal menulis Arab. Ujian tulis berupa Imla' atau dikte dalam menulis Arab.

4) Al-Qur'an

Ujian Al-Qur'an merupakan ujian untuk mengetahui bacaan santri dalam membaca beberapa ayat pilihan yang telah disiapkan dan melakukannya dengan bacaan yang benar dan tepat. Ujian Al-Qur'an tersebut meliputi Tajwid, makharijul huruf, dan kelancaran dalam membaca.

\section{HASIL DAN PEMBAHASAN \\ 4.1. Implementasi Sistem}

Pada halaman utama user terdapat beberapa tombol yaitu tombol get started dan graduation data. Tombol get started akan mengarahkan user pada halaman login untuk mengakses halaman admin. Tombol graduation data akan mengarahkan user untuk mengakses halaman data kelulusan. Tampilan interface halaman data kelulusan dapat dilihat pada Gambar 3. Pada halaman utama user juga terdapat informasi prosedur pendaftaran wisuda.

Pada halaman data kelulusan, user akan disajikan data kelulusan peserta. Pada halaman data kelulusan terdapat tombol detail untuk melihat detail data nilai yang diperoleh dan detail perhitungan untuk menentukan kelulusan. Tampilan interface halaman detail penilaian dapat dilihat pada Gambar 4 dan 5 . 


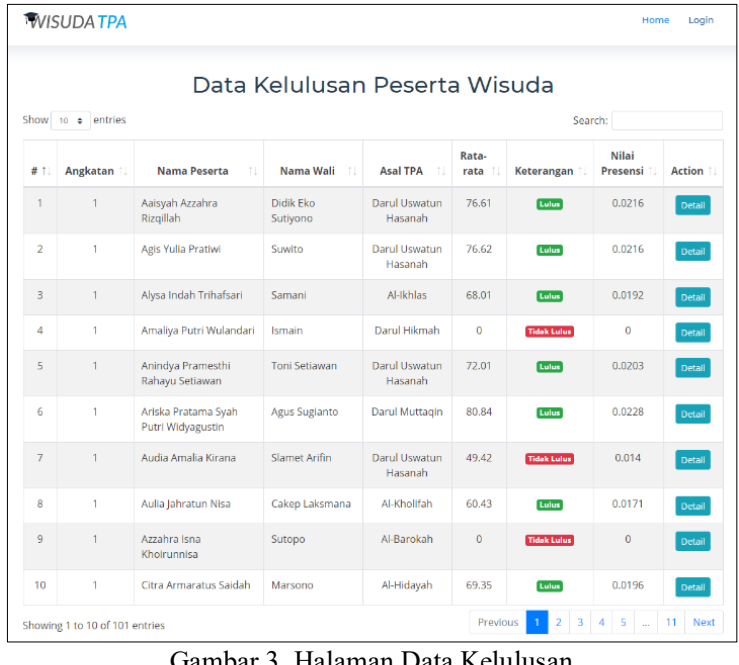

Gambar 3. Halaman Data Kelulusan

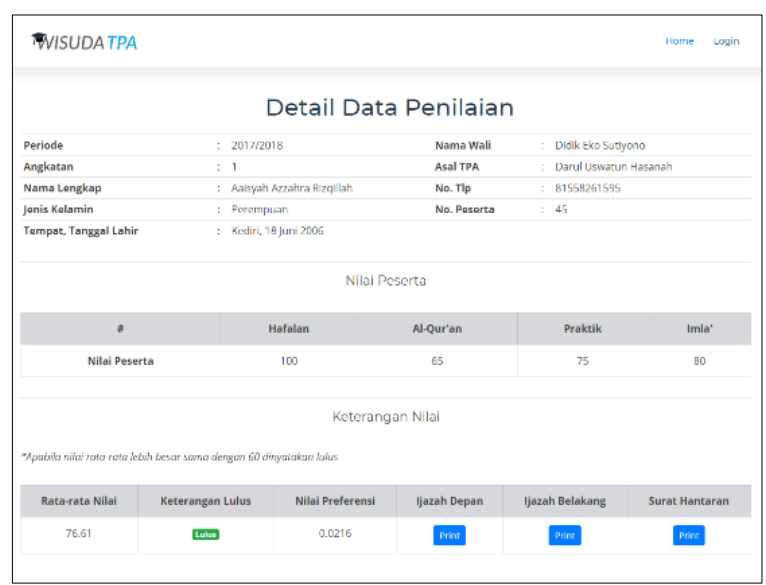

Gambar 4. Identitas dan hasil nilai peserta

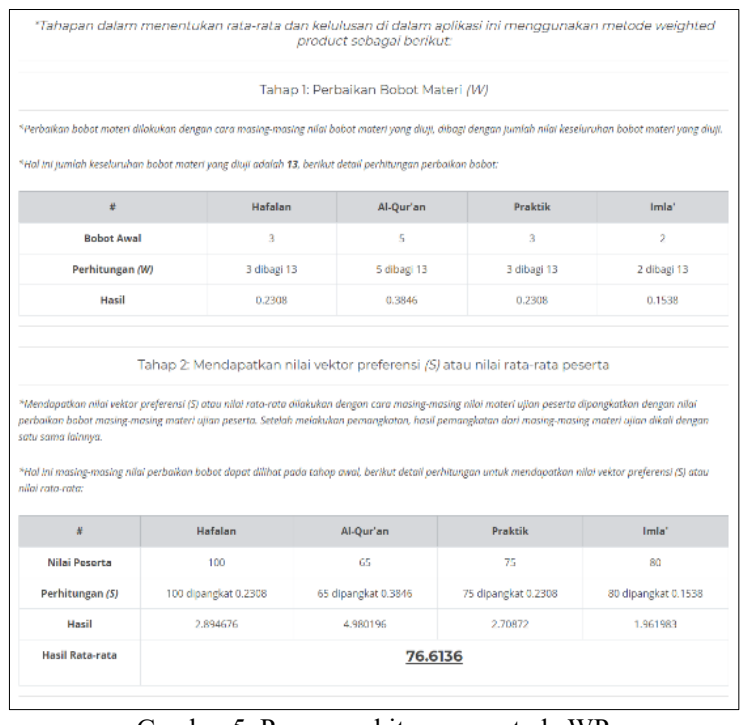

Gambar 5. Proses perhitungan metode WP

Pada halaman admin terdapat halaman menu penilaian. Halaman menu penilaian berfungsi untuk menampung data nilai materi peserta dan proses perhitungan untuk menentukan kelulusan seperti gambar 6.

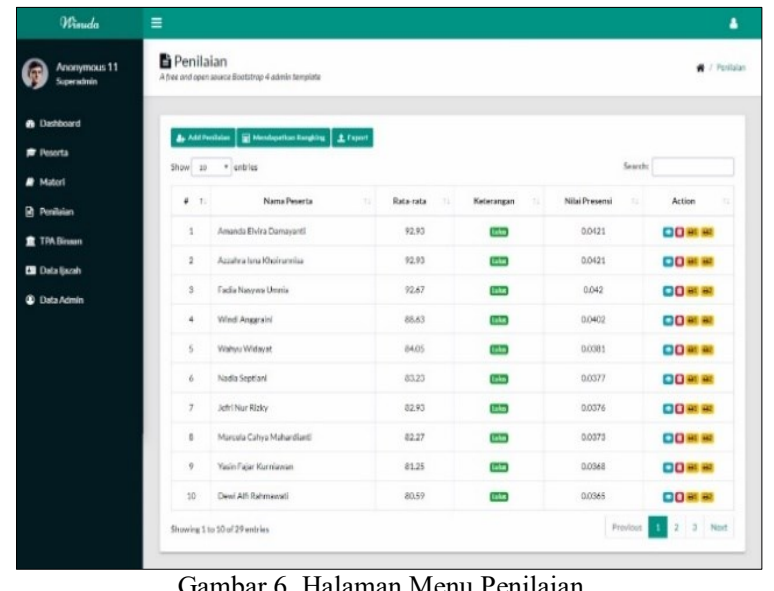

Gambar 6. Halaman Menu Penilaian

\subsection{Penentuan Kelulusan dengan Metode WP}

Sampel yang digunakan dalam proses penentuan kelulusan sebanyak 18 sampel. Proses perhitungan dalam menentukan kelulusan disajikan pada Tabel 3 hingga Tabel 6.

\begin{tabular}{ccccc}
\multicolumn{5}{c}{ Tabel 3. Hasil Matrik Keputusan } \\
\hline \multirow{2}{*}{ Alternatif } & \multicolumn{4}{c}{ Kriteria } \\
\cline { 2 - 5 } & $\boldsymbol{C}_{\mathbf{1}}$ & $\boldsymbol{C}_{\mathbf{2}}$ & $\boldsymbol{C}_{\mathbf{3}}$ & $\boldsymbol{C}_{\mathbf{4}}$ \\
\hline$A_{1}$ & 65 & 100 & 75 & 80 \\
\hline$A_{2}$ & 63 & 80 & 90 & 92 \\
\hline$A_{3}$ & 60 & 60 & 80 & 88 \\
\hline$A_{4}$ & 49 & 100 & 95 & 76 \\
\hline$A_{5}$ & 75 & 80 & 100 & 72 \\
\hline$A_{6}$ & 59 & 15 & 98 & 68 \\
\hline$A_{7}$ & 65 & 25 & 95 & 96 \\
\hline$A_{8}$ & 58 & 60 & 95 & 84 \\
\hline$A_{9}$ & 56 & 100 & 95 & 68 \\
\hline$A_{10}$ & 39 & 80 & 70 & 44 \\
\hline$A_{11}$ & 42 & 60 & 65 & 56 \\
\hline$A_{12}$ & 59 & 80 & 70 & 28 \\
\hline$A_{13}$ & 55 & 60 & 65 & 20 \\
\hline$A_{14}$ & 52 & 80 & 65 & 12 \\
\hline$A_{15}$ & 66 & 80 & 70 & 72 \\
\hline$A_{16}$ & 78 & 100 & 70 & 92 \\
\hline$A_{17}$ & 72 & 100 & 90 & 44 \\
\hline$A_{18}$ & 61 & 100 & 70 & 84 \\
\hline & & & &
\end{tabular}

Dengan $\mathrm{C} i$ adalah jenis ujian meliputi $\mathrm{C}_{1}=\mathrm{Al}$ Qur'an; $\mathrm{C}_{2}=$ Hafalan; $\mathrm{C}_{3}=$ Praktik; dan $\mathrm{C}_{4}=$ Tulis. Dari hasil penentuan matrik keputusan, kemudian dilakukan normalisasi bobot. Normalisasi dilakukan untuk mengalihkan hasil penilaian setiap kriteria.

\begin{tabular}{cccc}
\multicolumn{4}{c}{ Tabel 4. Hasil Normalisasi Bobot } \\
\hline$W_{1}($ norm $)$ & $W_{2}$ (norm) & $W_{3}($ norm $)$ & $W_{4}$ (norm) \\
$=\frac{5}{13}$ & $=\frac{3}{13}$ & $=\frac{3}{13}$ & $=\frac{2}{13}$ \\
\hline
\end{tabular}

Diketahui hasil normalisasi $W_{1}=0.385 ; W_{2}=0.231$; $W_{3}=0.231$; dan $W_{4}=0.154$. Setelah melakukan normalisasi bobot yaitu menentukan nilai vektor preferensi (S).

Vektor preferensi relatif merupakan preferensi alternatif yang akan digunakan untuk proses perangkingan masing-masing alternatif. Diketahui hasil penjumlahan nilai vektor preferensi (S) keseluruhan adalah 1163.74. 


\begin{tabular}{cccccc}
\multicolumn{6}{c}{ Tabel 5. Hasil Penentuan Nilai Vektor (S) } \\
\hline $\begin{array}{c}\text { Altern } \\
\text { atif }\end{array}$ & \multicolumn{5}{c}{$\begin{array}{c}\text { Kektor } \\
\text { Yreferen } \\
\text { si }(\boldsymbol{S})\end{array}$} \\
\cline { 2 - 6 } & $\boldsymbol{C}_{1}$ & $\boldsymbol{C}_{2}$ & $\boldsymbol{C}_{3}$ & $\boldsymbol{C}_{4}$ \\
\hline$A_{1}$ & $\left(65^{0.385}\right)$ & $\left(100^{0.231}\right)$ & $\left(75^{0.231}\right)$ & $\left(80^{0.154}\right)$ & 76.61 \\
\hline$A_{2}$ & $\left(63^{0.385}\right)$ & $\left(80^{0.231}\right)$ & $\left(90^{0.231}\right)$ & $\left(92^{0.154}\right)$ & 76.62 \\
\hline$A_{3}$ & $\left(60^{0.385}\right)$ & $\left(60^{0.231}\right)$ & $\left(80^{0.231}\right)$ & $\left(88^{0.154}\right)$ & 68.01 \\
\hline$A_{4}$ & $\left(49^{0.385}\right)$ & $\left(100^{0.231}\right)$ & $\left(95^{0.231}\right)$ & $\left(76^{0.154}\right)$ & 72.01 \\
\hline$A_{5}$ & $\left(75^{0.385}\right)$ & $\left(80^{0.231}\right)$ & $\left(100^{0.231}\right)$ & $\left(72^{0.154}\right)$ & 80.84 \\
\hline$A_{6}$ & $\left(59^{0.385}\right)$ & $\left(15^{0.231}\right)$ & $\left(98^{0.231}\right)$ & $\left(68^{0.154}\right)$ & 49.42 \\
\hline$A_{7}$ & $\left(65^{0.385}\right)$ & $\left(25^{0.231}\right)$ & $\left(95^{0.231}\right)$ & $\left(96^{0.154}\right)$ & 60.43 \\
\hline$A_{8}$ & $\left(58^{0.385}\right)$ & $\left(60^{0.231}\right)$ & $\left(95^{0.231}\right)$ & $\left(84^{0.154}\right)$ & 69.35 \\
\hline$A_{9}$ & $\left(56^{0.385}\right)$ & $\left(100^{0.231}\right)$ & $\left(95^{0.231}\right)$ & $\left(68^{0.154}\right)$ & 74.51 \\
\hline$A_{10}$ & $\left(39^{0.385}\right)$ & $\left(80^{0.231}\right)$ & $\left(70^{0.231}\right)$ & $\left(44^{0.154}\right)$ & 53.67 \\
\hline$A_{11}$ & $\left(42^{0.385}\right)$ & $\left(60^{0.231}\right)$ & $\left(65^{0.231}\right)$ & $\left(56^{0.154}\right)$ & 21.92 \\
\hline$A_{12}$ & $\left(59^{0.385}\right)$ & $\left(80^{0.231}\right)$ & $\left(70^{0.231}\right)$ & $\left(28^{0.154}\right)$ & 58.71 \\
\hline$A_{13}$ & $\left(55^{0.385}\right)$ & $\left(60^{0.231}\right)$ & $\left(65^{0.231}\right)$ & $\left(20^{0.154}\right)$ & 49.92 \\
\hline$A_{14}$ & $\left(52^{0.385}\right)$ & $\left(80^{0.231}\right)$ & $\left(65^{0.231}\right)$ & $\left(12^{0.154}\right)$ & 48.26 \\
\hline$A_{15}$ & $\left(66^{0.385}\right)$ & $\left(80^{0.231}\right)$ & $\left(70^{0.231}\right)$ & $\left(72^{0.154}\right)$ & 70.88 \\
\hline$A_{16}$ & $\left(78^{0.385}\right)$ & $\left(100^{0.231}\right)$ & $\left(70^{0.231}\right)$ & $\left(92^{0.154}\right)$ & 82.64 \\
\hline$A_{17}$ & $\left(72^{0.385}\right)$ & $\left(100^{0.231}\right)$ & $\left(90^{0.231}\right)$ & $\left(44^{0.154}\right)$ & 75.81 \\
\hline$A_{18}$ & $\left(61^{0.385}\right)$ & $\left(100^{0.231}\right)$ & $\left(70^{0.231}\right)$ & $\left(84^{0.154}\right)$ & 74.14 \\
\hline & & & & & \\
\hline
\end{tabular}

\begin{tabular}{|c|c|c|}
\hline Alternatif & Vektor V & Rangking \\
\hline \multirow[b]{2}{*}{$A_{1}$} & 76.61 & \\
\hline & $\overline{1163.74}=0.0218$ & 4 \\
\hline \multirow[t]{2}{*}{$A_{2}$} & $76.62-00218$ & \\
\hline & $\overline{1163.74}=0.0218$ & 3 \\
\hline \multirow[t]{2}{*}{$A_{3}$} & 68.01 & \\
\hline & $\overline{1163.74}=0.0194$ & 11 \\
\hline \multirow[t]{2}{*}{$A_{4}$} & $72.01=00205$ & \\
\hline & $\overline{1163.74}=0.0205$ & 8 \\
\hline \multirow[t]{2}{*}{$A_{5}$} & $80.84-00230$ & \\
\hline & $\overline{1163.74}=0.0230$ & 2 \\
\hline \multirow[t]{2}{*}{$A_{6}$} & $49.42-00141$ & \\
\hline & $\frac{1163.74}{114}=0.0141$ & 16 \\
\hline \multirow[t]{2}{*}{$A_{7}$} & $60.43-00172$ & \\
\hline & $\overline{1163.74}=0.0172$ & 12 \\
\hline \multirow[t]{2}{*}{$A_{8}$} & $69.35-00108$ & \\
\hline & $\overline{1163.74}=0.0198$ & 10 \\
\hline \multirow[t]{2}{*}{$A_{9}$} & 74.51 & \\
\hline & $\overline{1163.74}=0.0212$ & 6 \\
\hline \multirow[t]{2}{*}{$A_{10}$} & 53.67 & \\
\hline & $\overline{1163.74}=0.0153$ & 14 \\
\hline \multirow[t]{2}{*}{$A_{11}$} & $21.92-00062$ & \\
\hline & $\overline{1163.74}=0.0062$ & 18 \\
\hline \multirow[t]{2}{*}{$\overline{A_{12}}$} & 58.71 & \\
\hline & $\overline{1163.74}=0.0167$ & 13 \\
\hline \multirow[t]{2}{*}{$A_{13}$} & $49.92-00142$ & \\
\hline & $\overline{1163.74}=0.0142$ & 15 \\
\hline \multirow[t]{2}{*}{$\overline{A_{14}}$} & $48.26-00137$ & \\
\hline & $\overline{1163.74}=0.0137$ & 17 \\
\hline \multirow[t]{2}{*}{$A_{15}$} & 70.88 & \\
\hline & $\overline{1163.74}=0.0202$ & 9 \\
\hline \multirow[t]{2}{*}{$\overline{A_{16}}$} & $82.64-00225$ & \\
\hline & $\overline{1163.74}=0.0235$ & 1 \\
\hline \multirow{2}{*}{$A_{17}$} & $75.81-00216$ & \\
\hline & $\overline{1163.74}=0.0216$ & 5 \\
\hline \multirow[t]{2}{*}{$A_{18}$} & $74.14=00211$ & \\
\hline & $\overline{1163.74}=0.0211$ & 7 \\
\hline
\end{tabular}

Hasil dari pengujian sistem diperoleh dari hasil keputusan 18 sampel yang digunakan, perangkingan menunjukkan bahwa alternatif tertinggi yaitu Faruq Febriananta $\left(A_{16}\right)$ dengan nilai vektor $(S) 82.64$ dan nilai vektor $(V) 0.0235$.

\subsection{Pengujian Sistem dengan Metode Black Box Testing}

Metode Black box digunakan untuk menemukan hal-hal berikut: 1) Fungsi yang tidak benar atau tidak ada; 2) Kesalahan antarmuka 3) Kesalahan pada struktur data dan akses basis data; 4)
Kesalahan performansi 5) Kesalahan inisialisasi dan terminasi (Mustaqbal, Firdaus dan Rahmadi, 2015). Proses pengujian dalam penelitian ini dibagi menjadi dua kategori yaitu pengujian halaman user dan halaman admin.

\begin{tabular}{|c|c|c|c|}
\hline \multirow{2}{*}{ No } & \multirow{2}{*}{$\begin{array}{c}\text { Rancangan } \\
\text { Proses }\end{array}$} & \multirow{2}{*}{$\begin{array}{l}\text { Luaran yang } \\
\text { diharapkan }\end{array}$} & Validitas \\
\hline & & & $\mathbf{Y}$ \\
\hline 1 & Tombol detail & $\begin{array}{l}\text { Mengarah ke halaman } \\
\text { detail nilai }\end{array}$ & $\mathrm{Y}$ \\
\hline 2 & Tombol print & $\begin{array}{l}\text { Mendapatkan data nilai } \\
\text { dalam bentuk desain } \\
\text { ijazah berextensi .pdf }\end{array}$ & $\mathrm{Y}$ \\
\hline 3 & $\begin{array}{l}\text { Icon user pada } \\
\text { header }\end{array}$ & $\begin{array}{l}\text { Mengarah ke halaman } \\
\text { login }\end{array}$ & $\mathrm{Y}$ \\
\hline 4 & $\begin{array}{l}\text { Login akun } \\
\text { salah }\end{array}$ & alert informasi kesalahan & $\bar{Y}$ \\
\hline 5 & Login & Masuk halaman admin & $\mathrm{Y}$ \\
\hline \multicolumn{4}{|c|}{ Tabel 8. Pengujian Halaman Admin } \\
\hline \multirow{2}{*}{ No } & \multirow{2}{*}{$\begin{array}{c}\text { Rancangan } \\
\text { Proses }\end{array}$} & \multirow{2}{*}{$\begin{array}{l}\text { Luaran yang } \\
\text { diharapkan }\end{array}$} & Validitas \\
\hline & & & $\mathbf{Y}$ \\
\hline 1 & $\begin{array}{l}\text { Halaman } \\
\text { utama admin }\end{array}$ & $\begin{array}{l}\text { Tampil statistik } \\
\text { kelulusan }\end{array}$ & $\mathrm{Y}$ \\
\hline 2 & $\begin{array}{l}\text { Insert materi } \\
\text { dan nilai bobot }\end{array}$ & $\begin{array}{l}\text { Data tersimpan di } \\
\text { database }\end{array}$ & $\mathrm{Y}$ \\
\hline 3 & $\begin{array}{l}\text { Normalisasi } \\
\text { bobot }\end{array}$ & $\begin{array}{l}\text { Mendapatkan nilai } \\
\text { sesuai dengan data } \\
\text { materi aktif }\end{array}$ & $\mathrm{Y}$ \\
\hline 4 & $\begin{array}{l}\text { Insert nilai } \\
\text { peserta }\end{array}$ & $\begin{array}{l}\text { Data tersimpan di } \\
\text { database }\end{array}$ & $\mathrm{Y}$ \\
\hline 5 & Tombol hitung & $\begin{array}{l}\text { Mendapatkan nilai } \\
\text { vektor (S) dan ketentuan } \\
\text { lulus }\end{array}$ & $\mathrm{Y}$ \\
\hline 6 & $\begin{array}{l}\text { Tombol } \\
\text { perangkingan }\end{array}$ & $\begin{array}{l}\text { Mendapatkan nilai } \\
\text { vektor (V) sesuai dengan } \\
\text { tahun dan data di } \\
\text { database }\end{array}$ & $\mathrm{Y}$ \\
\hline
\end{tabular}

Dari hasil keseluruhan pengujian sistem pada Tabel 7 dan 8 dapat disimpulkan bahwa fitur yang terdapat di masing-masing halaman aplikasi telah berfungsi sebagaimana mestinya.

\subsection{Uji Coba Pengguna}

Hasil penyebaran lembar kuesioner terhadap administrator memiliki hasil rata-rata pertanyaan sejumlah 4.29 dengan tingkat kepuasan "tinggi". Hasil penyebaran lembar kuesioner terhadap user memiliki hasil rata-rata pertanyaan sejumlah 4.64 dengan tingkat kepuasan "sangat tinggi". Hasil ratarata keseluruhan pertanyaan yang diajukan kepada administrator dan pengguna selaku entitas/user aplikasi memiliki rata-rata hasil 4.47 dengan tingkat kepuasan "tinggi".

Penelitian selanjutnya perlu diterapkan metode lain yang lebih baik akurasinya dibandingkan dengan metode WP. Diantara metodenya adalah PROMETE, ELEKTRE (Kolios, Mytilinou and Lozano-minguez, 2016) dan SAW (Wira Trise Putra and Agustian Punggara, 2018). Diharapkan dari penerapan metode lain yang diusulkan akan menambah akurasi nilai yang lebih baik. 


\section{KESIMPULAN}

Hasil penerapan metode weighted product dalam proses seleksi santri calon wisuda dapat memberikan nilai bobot yang berbeda pada setiap tahapan ujian. Hasil pengujian sistem menggunakan metode black box menunjukkan halaman aplikasi telah berfungsi sebagaimana mestinya. Hasil uji coba pengguna mendapatkan hasil dengan tingkat kepuasan tinggi. Dari hasil dan pengujian dapat disimpulkan bahwa aplikasi telah layak digunakan dan hingga saat ini dioperasikan untuk menyeleksi kelulusan santri wisuda TPA binaan UNIDA Gontor.

\section{DAFTAR PUSTAKA}

KHAIRINA, D.M., IVANDO, D. AND MAHARANI, S., 2016. Implementasi Metode Weighted Product Untuk Aplikasi Pemilihan Smartphone Android. JURNAL INFOTEL - Informatika Telekomunikasi Elektronika, [online] 8(1), p.16. Available at:

$<$ http://ejournal.st3telkom.ac.id/index.php/i nfotel/article/view/47>.

KOLIOS, A., MYTILINOU, V. AND LOZANOMINGUEZ, E., 2016. A Comparative Study of Multiple-Criteria DecisionMaking Methods under Stochastic Inputs. Energies, 9(7), pp.1-21.

MAHARANI, S., HERMAWATI, S., ASTUTI, I.F. AND KHAIRINA, M., 2018. Pemilihan Taman Kanak-kanak Menggunakan Metode Weighted Product di Kecamatan Sungai Kunjang Samarinda. Jurnal Teknologi Informasi dan Ilmu Komputer, [online] 5(4), p.465. Available at: $<$ http://jtiik.ub.ac.id/index.php/jtiik/article/ view/814>.

MUSTAFIDAH, H. AND HADYAN, H.N., 2017. Sistem Pendukung Keputusan Penentuan Mahasiswa Berprestasi di Universitas Muhammadiyah Purwokerto Menggunakan Metode Weighted Product (WP). Juita, V(1), pp.51-61.

MUSTAQBAL, M.S., FIRDAUS, R.F. AND RAHMADI, H., 2015. Pengujian Aplikasi Menggunakan Black Box Testing Boundary Value Analysis. Jitter, I(3), pp.31-36.

NOFRIANSYAH, D. AND DEFIT, S., 2017. Multi Criteria Decision Making (MCDM): pada sistem pendukung keputusan. [online] Yogyakarta: Deepublish. Available at: $<$ https://opac.perpusnas.go.id/DetailOpac.a spx?id=1070819\#>.

PURWANDANI, A.R., HUSODO, A.Y. AND BIMANTORO, F., 2019. Analisis Efektifitas Metode Weighted Product dan TOPSIS dalam Mendiagnosa Serangan
Asma. Journal of Computer Science and Informatics Engineering (J-Cosine), [online] 3(1), pp.1-9. Available at: $<$ https://jcosine.if.unram.ac.id/index.php/jc osine/article/view/185>.

SOMMERVILLE, I., 2010. Software Engineering. 9th ed. Software Engineering. USA: Addison-Wesley Publishing Company.

SUCIPTO, S., 2017. Analisa Hasil Rekomendasi Pembimbing Menggunakan Multi-Attribute Dengan Metode Weighted Product. Fountain of Informatics Journal, [online] 2(1), p.27. Available at: $<$ http://ejournal.unida.gontor.ac.id/index.ph $\mathrm{p} / \mathrm{FIJ} /$ article/view/912>.

Universitas Darussalam Gontor, 2018. TPA Binaaan UNIDA Luluskan 41 Santri pada Wisuda Perdananya. unida.gontor.ac.id.

WIRA TRISE PUTRA, D. AND AGUSTIAN PUNGGARA, A., 2018. Comparison Analysis of Simple Additive Weighting (SAW) and Weigthed Product (WP) In Decision Support Systems. MATEC Web of Conferences, [online] 215, p.01003. Available at: <https://www.matecconferences.org/10.1051/matecconf/201821 501003>. 
Halaman ini sengaja dikosongkan 